\title{
Decoding Hegemony: Exploring the Discourse of a Prosecuting Elite
}

\author{
Robyn L Holder
}

November 2017

\begin{abstract}
Author's Note
Correspondence concerning this article should be addressed to Robyn Holder, Griffith Criminology Institute, Griffith University, Mt Gravatt Campus, 176 Messines Ridge Road, Mt Gravatt, Queensland 4122, Australia. Phone: +61 (0) 737353440 Fax: +61 (0) 737356812 Email: $\underline{\text { r.holder@griffith.edu.au }}$
\end{abstract}

This is a pre-publication version of a chapter accepted for the forthcoming collection, The Evolving Role of the Public Prosecutor, edited by Victoria Colvin and Philip Stenning for Routledge.

Please refer to the published version for correct page citations.

C Robyn Holder 13 November 2017 


\title{
Decoding Hegemony: Exploring the Discourse of a Prosecuting Elite
}

\author{
Robyn L Holder
}

November 2017

\begin{abstract}
Public prosecution authorities are a relatively recent institutional development within common law criminal justice systems. Although prosecution occupies a critical place within criminal justice, it is under-researched. Those who work as prosecutors are an even greater unknown. They rarely give a public account of themselves. Their views are veiled in the language of neutrality and restraint. This chapter presents analysis of the discourse of a small group of exDirectors of Public Prosecution from six different jurisdictions in Australia. The reflections of this elite group are used as a single narrative in order to identify and map their core organising concepts. The chapter works through different depictions of intellectual and technical elites as high mandarins to explore how power works in contemporary criminal justice.
\end{abstract}




\title{
Decoding Hegemony: Exploring the Discourse of a Prosecuting Elite
}

\author{
Robyn L Holder
}

\section{Introduction}

In today's world the institutions of criminal justice are imbued with an extraordinary degree of power and authority over ordinary citizens. Mostly this is indirect and criminal justice lies in the background of people's everyday lives. Whereas police and the courts are sharper in focus, prosecutors conduct their business largely unseen in the public eye. This chapter explores their hidden power through the discourse of a prosecuting elite. As 'high mandarins' they do not produce case law and are parsimonious in their production of 'treatise literature'; rather they produce, apply and interpret law in liminal spaces (Gordon 1984: 120; Blumenthal 2012). Partially this is done through definitional authority and the exercise of discretion. This capacity allows prosecutors to represent 'reality', delineate what is possible and what is not, and to decide who is and is not a legitimate subject of the law's application. This chapter traces the contours and strands of prosecution thinking in guarded appreciation. Prosecutors carry enormous responsibility. Nonetheless the chapter's ultimate aim is to situate the discourse within a political frame that highlights prosecution as an organ of the state. ${ }^{1}$ From this standpoint the seeming benevolence of the mandarin administrator demands more forensic illumination.

\section{Looking at public prosecution}

While comparatively under-studied, in recent years prosecution has attracted growing scholarly interest. Studies have tended to fall into a number of categories. One body of work describes prosecution forms, functions and authority, often in comparative studies. ${ }^{2}$ Another has

\footnotetext{
${ }^{1}$ I extend Iris Marion Young's conception of 'the political' (1987: 73) in order to attend to the relationship of ordinary people to the state (through its institutions).

2 The edited collection from Luna and Wade (2012) provide sections on prosecution in particular countries, in transnational perspective, and comparing contemporary challenges. For comparisons across Europe see Wade, de
} 
examined the outcomes that flow from prosecution decisions and the effects on criminal justice and criminal policy more generally (Tonry 2012). These especially focus on the exercise of prosecution discretion regarding different offences, characteristics of the accused or victim, and criminal justice decision-making more generally. ${ }^{3}$ Others have examined the interactions between prosecutors and other criminal justice actors in shaping institutional practices and forming organisational cultures. ${ }^{4}$ The burgeoning institutions of international criminal justice have generated considerable attention to the office of the prosecutor (Reydams et al. 2012). In combination, studies describe an organisation that is critical to the functioning of criminal justice systems, its efficiency and its calibration with social and legal norms in charged environments.

Yet those who work as prosecutors, who they are and what they think, are a great unknown. One recent United States study considered diversity amongst prosecutors and between prosecution offices. Researchers interviewed over 200 prosecutors from nine offices across southern states in the US. The study found differences in the 'social architecture' of offices, their sense of 'balance', and their 'sense of belonging to the wider legal community' (Wright et al. 2014: 28). These differences related in part to whether prosecutors were 'rookies' or 'veterans'. The latter identified more as 'lawyers' than prosecutors. They were less trialoriented and more collegiate with defence counsel. They saw themselves and their views situated within a system of checks and balances (Wright and Levine 2014).

While prosecutors as a workforce may have been rendered a little less anonymous through this research, those who perform the leadership role are only slightly more visible. Chief Prosecutors ${ }^{5}$ share surface similarity and network through transnational organisations

\footnotetext{
Cavarlay and Zila (2008); across common law countries see Sanders (1996), and for discussions about similarities and differences between prosecution in the United States and Japan see Johnson (2002) and in relation to Switzerland, France and Germany see Gillieron (2014).

${ }^{3}$ There are many examples to draw from in this category. For example, for Europe see Jehle and Wade (2008); for the USA see Davis (2007) and Sarat and Clarke (2008); for England see King (2000); in international criminal justice see Brubacher (2004); and for Australia see Lievore (2005).

${ }^{4}$ In the USA see, for example, Mellon et al. (1981), and in England see Rock (2004).

${ }^{5}$ The Head of a Public Prosecution Office is known by different names in different countries. In this chapter Chief Prosecutor and Director of Public Prosecutions are used interchangeably.
} 
such as the International Association of Prosecutors. ${ }^{6}$ Yet different histories, different legal and social environments, and different political and legislative mandates unsettle comparative assumptions. For example, in the United States where state chief prosecutors are elected and federal US attorneys are appointed, there is more visibility in terms of career aspiration, career trajectory and leaders' impact (Bandyopadhyay and McCannon 2014; Boylan 2005; Eisenstein 1978). However, in other common law countries Chief Prosecutors rarely give a public account of themselves.

This is not to say that Chief Prosecutors do not speak in public. Rather their public appearances tend to be formal affairs in which they present their legislative mandate, set out their function, and elaborate prosecution policy (Bugg 2007; Refshague 2002). They barely hint at the manner in which 'changes in social conditions' influence a Director's decision-making (Hetherington 1987: 10). The occasional memoir has illuminated working contexts. Every day, said one ex-Director, almost every decision 'would make somebody unhappy' (Cowdery 2012: 220). Another reflected on her many disappointing encounters with the powerful (Del Ponte 2011). These individual accounts speak to the highly political environments in which Chief Prosecutors work.

\section{Conversations with 'high mandarins'}

This chapter acknowledges that environment by styling prosecution leaders as mandarins. The narrative of six ex-Directors of Public Prosecution in Australia is used as 'mandarin materials' to de-code institutional logic (Gordon 1984: 120). ${ }^{7}$ Elites such as these are of interest to researchers because of their close proximity to or exercise of power (Morris 2009). They are masters of specialised forms of knowledge 'embedded in processes of modernisation' (Meuser and Nagel 2009: 17). Elites are objects of study because 'it matters who rules' (Conti and O'Neil 2007: 65).

\footnotetext{
${ }^{6}$ The Association (IAP) was established in 1995 to respond to the problem of transnational crime. It also works to set and raise the standards of conduct and ethics for prosecutors. For more information about the IAP, go to www.iap-association.org/.

${ }^{7}$ The interviews were conducted as part of doctoral research that examined lay and legal ideas about justice (Holder 2013).
} 
Interviewing elites and experts comes with the usual problem for researchers of accessibility, but present additional challenges by virtue of their expertise (Morris 2009). Public service elites such as Directors of Public Prosecution are also highly attuned to the political nature of their utterances. They are positioned differently to the researcher and, through the interview, actively shape the creation of knowledge (Conti and O'Neil 2007). However, as an elite, theirs is not posed as 'truth' or a source of objectivity. Rather, their disciplinary and institutional settings impose 'cognitive and social norms' that are habituated and routinised in their professional lives (Meuser and Nagel 2009: 20). In their professional lives the ex-Directors can be viewed both as agents and as acted upon; but in their aggregated discourse they are more than individuals.

For this research approaches were made to people who had been (but were no longer) Directors of Public Prosecution in Australia. Directors have experience and expertise in their field. Ex-Directors were further assumed to have greater latitude to speak freely about the tensions and challenges to the role. There are nine criminal jurisdictions in the Australian federal system. ${ }^{8}$ From these, 15 potential respondents were identified through a key informant and an internet search. Eight persons were approached directly with a request for an interview. Six persons accepted the invitation. ${ }^{9}$ The six had practiced as Directors in six different criminal jurisdictions. Between them they had over fifty-one years of prosecuting experience and all were still active in other legal roles at the time of interview. Semi-structured interviews allowed for improvisation. Interviews were conducted in 2011 and comprised over 10 hours of conversation in total. The interviewees were assured that no personal or professional characteristics would be used to identify them. All were interviewed in a professional setting; surroundings that created a meta-narrative of authoritative ease.

\footnotetext{
${ }^{8}$ Within the Australian federation each State and Territory and the Commonwealth has an independent Office of Public Prosecution thus making nine offices. In most States and Territories police prosecutors operate in summary proceedings and an independent DPP conducts indictable prosecutions. Independent prosecution offices cost $\$ 303$ million per year in 2011-2012 (excluding the cost of police prosecution and the Commonwealth Director of Public Prosecutions). Alongside the cost of law enforcement, corrections and criminal courts, independent prosecuting offices account for the smallest criminal justice expenditure. Sourced at http://www.aic.gov.au/publications/current\%20series/rpp/121-140/rpp129/21-criminal-justice-system.html [retrieved 25 June 2016]

${ }^{9}$ One (ex) senior prosecutor undertook an interview as a pilot. This interview is not included in the analysis.
} 
Discourse analysis treats individual reflections as a whole and as connected to the production and reproduction of power (Chouliaraki and Fairclough 1999). In single narrative form the interviews identify and map institutional orthodoxies. Interview quotations are deidentified but differentiated numerically from P1 to P6. In the first section, the ex-Directors narrate depictions of their mandarin status. The discourse is then briefly situated within the evolution of prosecution in the Australian context. Following sections then amplify core 'codes' to the institutional logic of public prosecution embedded within the discourse.

\section{Mandarin: administrative and doctrinal}

A mandarin denotes a high official or bureaucrat in imperial China. This image of mandarin presents prosecution administrators as 'just one cog in the process' (P3). They are pragmatic actors who prosecute 'because you have a case' (P1). Theirs is a modest role to act 'professionally with the body of evidence and wherever that and the law and the guidelines take him or her' (P3). This managerialist picture ${ }^{10}$ distances prosecution from the exercise of substantive authority.

For the mandarin administrator, criminal law is a piece of equipment - a 'mechanism' (P1, P4) and a 'brake' (P5). Sometimes it is 'more like a sledge hammer than a jeweller's pliers' (P1) and 'pretty blunt' (P5). Law is a means to various ends. ${ }^{11}$ It is a mechanism 'for keeping order ... for controlling the power of other public officials ... for protecting the community ... for publicly expressing the community view of what ought to or ought not to be permitted ... And essentially in its day-to-day activities it is a mechanism by which persons accused of things are prosecuted and dealt with' (P1). As an instrument, the criminal law is explained as a means 'to ensure that the society can be managed in a way that allows people to get the benefits from the society' and 'to regulate and promote positive interaction' (P4). These are administrators who are responsible, moderate and unsentimental.

\footnotetext{
${ }^{10}$ In the European context, this is sometimes also described as 'actuarial justice' (Wade 2008).

${ }^{11}$ These sentiments echo realist approaches to law. Karl Llewellyn, for example, posed law as a functional system doing 'law-jobs' (Wacks 2006: 94).
} 
Ideas of delivering justice in daily practice are articulated as being 'professional' because 'on a day-to-day basis you run the case that you are doing ... the process takes over and you hope in some sort of way ultimately that it gets to, in general terms, a just result' (P1). As professionals they do 'the best we can with the tools we have' (P2) to 'achieve a generally acceptable outcome' (P3) 'according to the law' (P1). Doing the best one can is described as scrutinising the case 'as closely as you can' because 'justice can't be perfect' (P2). Not doing this means not being 'properly prepared' and being unable or unwilling to make an 'effort at persuasion' (P2). Justice is a bureaucratic 'mission' (P6). That is, to be independent, professional, effective, to operate with integrity and to be fair and just. As mandarin administrators they do not deal with 'some abstract concept of justice' (P1).

Abstract notions do emerge through statements that, as Directors, they are 'ministers of justice' (P4, P5). ${ }^{12}$ Pressed to describe justice in this guise and 'I suppose you come out with a few basic things like convict the guilty and acquit the innocent, fairness, fair trial, sentences that were proportionate' (P4). At this end of their representational spectrum prosecutors take this 'responsibility really really seriously' (P2). They will typically refer to their 'duty' (P1, P4, P5, P6) and 'obligation' (P1, P4) and invoke higher, if vague, principles. As doctrinal mandarins, prosecutors model constraint (P4). ${ }^{13}$ Being fair and just is 'broad overall consistency', 'equality of treatment' (P5), 'dealing with the individual fairly' (P6), and ensuring that 'the same test applies to you and to me but not one for the high profile cases and not for others' (P2).

From their position as 'ministers of justice' ex-Directors emphasise criminal law's normative expression of 'what ought to or ought not to be permitted' (P1) and as drawing 'the lines within which the community can comfortably live' (P4). It is 'the first and most basic system of norms' that any society - democratic or despotic - requires (P5). Furthermore, these norms involve 'moral wrongdoing easily recognised and readily acceptable throughout the

\footnotetext{
${ }^{12}$ A contemporary statement about this 'Minister for Justice' role is found in NSW Director of Public Prosecutions (2007), Prosecution Policy, Office of the Director of Public Prosecutions, Sydney, p.5. For argument that the notion of the prosecutorial 'minister of justice' is out-dated see Plater (2011), and over-stated see Young and Sanders (2004).

${ }^{13}$ Constraint is one component to the Minister of Justice conception of prosecution (Plater 2011: 162). For an example of the reference see NSW DPP (2007: 5).
} 
world' (P5). Law's multiple relationship(s) to peoples range from it as a 'subservient construct on society' (P4) to it as a 'guard' (P2).

These pictures of the administrative and the doctrinal mandarin appear to suggest a disjuncture between the mundane and the lofty. However, the combination of administrative practice and the claim as buttress of social stability is the precise feature that generates real and discursive authority. Discretionary decision-making directs attention 'to the low-lying details of how law makes itself felt' on a day-to-day basis (Gordon 2012: 205); and, as high officials, prosecutors 'project a discourse of inevitability and naturalness' (Harris 1997: 110). The ex-Directors associate law with an arc of social and political enlightenment, and appropriate and reformulate certain historical moments as inevitable modernisation.

\section{A civilising trajectory}

In England and Wales that modernisation rests on a long history of private initiation and carriage of proceedings, ${ }^{14}$ and a couple of centuries debate about establishing a comprehensive Crown Prosecution Service in 1985 (Rock 2004). However, the assertion of an organic and grounded evolution made in relation to the English common law and the lay institutions of magistracy, justices of the peace and village bobbies becomes something different during the dramatic rupture of a militarised penal and later settler colony of Australia (Godfrey and Dunstall 2005; Braithwaite 2001). The profound differences in social, economic and political practices - and not least in the geography of the colonies, dispersed European populations, and hostilities with Aborigines - caution against too many assumptions of commonality with English developments. The dispersed Australian colonies struggled to survive, literally and as emergent state identities (Hughes 1986).

Nonetheless contemporary ex-Directors assert that 'we came to this country with the Magna Carta in our back pockets' (P5) and 'inherited the English system lock, stock and barrel in the beginning' (P3). At the same time, both colonial and contemporary changes are seen to have shaped differences (P3) between the local and imperial systems (Neal 1991). Over time

\footnotetext{
${ }^{14}$ Although the sovereign absorption of criminal law occurred early in England, its enforcement and prosecution remained substantively in private hands well into the $18^{\text {th }}$ and $19^{\text {th }}$ centuries (Hay 1983; Langbein 2003).
} 
the systems of thought 'drift [...] apart' (P3) and, at the same time, remain 'closely aligned' (P5). There is clearly some elasticity to tradition. But the trends towards institutionalising, centralising and standardising of criminal practice and procedure that commenced in the nineteenth century and accelerated in the twentieth in England were similar if not more pronounced in Australia (Woods 2002). Yet it would not be until the 1980s and 90s that independent prosecuting authorities were established in the Australian states and territories. ${ }^{15}$

Although public prosecution offices were latecomers to the architecture of criminal justice, the discourse of ex-Directors attached to a larger narrative about the civilising trajectory of English legal history. The association of criminal law with the taming of human societies gains power not simply through its air of inexorability but in depictions of a history -claimed as Australia's inheritance (P1-P6) - 'that occurred over hundreds and hundreds of years' (P5). In particular, successive efforts from the twelfth century to introduce 'the concept of offences being a breach of the King's peace' are given as foundational to the present idea of criminal offences being committed against 'the public' rather than against individual members of that public (Kearon and Godfrey 2007: 19-20). The origin of British criminal law, it is claimed, 'was to prevent victims from taking the law into their own hands' (P1). Without law 'a society ... is anarchic, out of control' (P1). Indeed, law both accompanies and assists the move out of 'the realm of stone-age thinking' (P5). Vengeance was the past; public ownership of criminal law is the civilised present.

The construction of a history that is 'generally enlightened, humanitarian and progressive' (Emsley 2005: 2) ${ }^{16}$ emerges from an image of medieval brutishness (P1), to claim liberty against autocracy (P3), then the disinterested professionalising of a 'flawed' process (P4), and finally to provide stern independence of decision-making against the venality and arbitrariness of a politician - Attorney-General or other (P2, P3, P5). Moreover, through the

\footnotetext{
${ }^{15}$ In 1896 the first police prosecution department was established in Van Diemen's Land (now Tasmania). Directors of Public Prosecution began in 1973 with Tasmania (established by statute later in 1986), Victoria (1982), Queensland and the Commonwealth (1984), NSW (1986), the ACT (1990), Western Australia and the Northern Territory (1991) and South Australia (1992). To date, only in the Commonwealth, Tasmania and the ACT is the Director of Public Prosecutions responsible for both summary and indictable matters.

${ }^{16}$ This claim is critiqued by democracy theorists such as Carole Pateman (1970).
} 
flow of history, criminal law is said to claim 'a common core of values' that reaches back to the Babylonian era and is found infused in the world's major religions (P5).

These statements about the criminal law invariably draw on an account of social, legal and political historical change that steadily progresses towards liberal democratic capitalism and which systems of laws naturally and properly enable. Emphasised variously as a civilising process (Elias 1939), as 'the solidarity project' (Garland 2001), and as 'the Enlightenment project' (Lacey 2001), these changes are posed as following a linear path with an air of inevitability: 'as time progressed' (P1) informal or fragmentary rules would 'gradually solidify' in 'an evolutionary process' (P4). In the discourse, these historical references constitute markers in a 'chain of legitimation' (Bourdieu 1987: 824).

\section{Contemporary guardians of core prosecution concepts}

As markers these provide a kind of reconstructed logic to the appearance of public prosecution in both Australia and England. But the new, modern prosecution office is also 'organized around a body of internal protocols and assumptions, characteristic behaviours and self-sustaining values' (Terdiman 1987: 806). The legislative framework and published guidelines for public prosecution share certain classifying concepts such as independence, representing community and public interest. ${ }^{17}$ It is through these core concepts, as internal and institutionalised patterns of knowledge, that the remainder of the chapter arranges ex-Directors' discourse.

\footnotetext{
${ }^{17}$ In Australia each prosecuting authority publishes its own guidelines. However, there is broad commonality between them. Commonwealth Director of Public Prosecutions (2008), Prosecution Policy of the Commonwealth; Director of Public Prosecutions (NSW) (2007), Prosecution Guidelines of the Office of the Director of Public Prosecutions; Director of Public Prosecutions (ACT) (1991), Prosecution Policy and Guidelines of the Director of Public Prosecutions (ACT); Director of Public Prosecutions (NT) (2005), Director of Public Prosecutions Guidelines; Director of Public Prosecutions (Qld) (2003), Directors Guidelines; Director of Public Prosecutions (SA) (1992), Prosecution Policy; Director of Public Prosecutions (Tas) (1994), Director Public Prosecutions Guidelines; Office of the Director of Public Prosecutions (Vic) (2010), Director of Public Prosecutions Policy; Director of Public Prosecutions (WA) (2005), Statement of Prosecution Policy and Guidelines.
} 


\section{Independence}

Prosecutorial independence is a prized attribute and signifier. ${ }^{18}$ Independence is maintained against a number of influences: from politics, police and the public. Its special significance is claimed in the first instance against politicised interference in the form of actions (or inactions) of recent and long past Attorneys-General (P2, P3, P5, P6). Prosecution was in private hands probably until the 1880s, 1890s when the first Director of Public Prosecutions was appointed. It was in political hands in this country for a very long time. The Attorneys-General used to do it ... they are basically politicians.' This came to be 'regarded as quite wrong [ ...] that they should be making decisions about persons [where] they might be beholden' (P6).

Independence from political intrusion is also pragmatic. Directors of Public Prosecution (DPP) tend to say to Attorneys-General 'don't try and second guess us because once you do that you buy into the argument and then you have to make the decision. One of the points about having a DPP is to have someone else making the decision and wear the opprobrium' (P4). It also recognised that prosecution is an intrusive power - 'it is the line that protects everybody because one day, who is to say that a weakened and futile prosecution ought to be run this week but not next week?' (P2).

While police have a more extensive history in prosecuting, ${ }^{19}$ prosecution independence from police as investigators assumed greater significance over the twentieth century (Rozenes 1996). In England and Wales, this is claimed in relation to a succession of miscarriages of justice (McConville and Wilson 2002: 155; Hetherington 1989) and, in Australian jurisdictions with police prosecutors, to more generalised concerns about probity if not outright corruption (Krone 2003). Here the argument is that police seek to 'win at all costs' whereas the obligation of justice institutions is to abide 'by your oath to act according to the law' (P1). Nonetheless there is a continuum from, at one end, an ethical stance about what is the 'appropriate moral

\footnotetext{
${ }^{18}$ When asked what were the three greatest qualities of his office, Nicholas Cowdery QC, then NSW Director of Public Prosecutions, said 'independence, independence, independence' (Cowdery, N. (1995). Hot Seat or Siberia. Journal of the NSW Bar Association, vol.5).

${ }^{19}$ For a discussion on the historical evolution in Australia see Corns (2000).
} 
censure' a prosecutor seeks (Young and Sanders 2004: 194), to understanding, at the other end, 'that every prosecutor ever born wants the person to be found guilty' (P6). ${ }^{20}$

Finally, argument about independence finds traction in the day-to-day decision-making of prosecutors. Here independence is not being told what to do, whoever was expressing a preference. Discretionary decision-making both indicates independence and enacts it. A noble rationale is that discretion 'is a tool indispensable for the individualisation of justice' (Davis 1975). More prosaically it 'allows for compromise and expediency' (Findlay et al. 2010: 114). Without discretion it is said 'our system would grind to a halt' (P5). While there are different perspectives on discretion and the independent role, ${ }^{21}$ there is a shared view of what it is not; that is, being directed by an individual what to do - it is 'quite wrong to [prosecute] because the victim wants to' (P1). Rather, it is a matter of 'professional judgment' (P1) framed by 'extensive' guidelines (P3, P6).

Contemporary prosecutors assert their independence in a charged environment. Some claim 'there was a period when what the Director said was not questioned, it was accepted publicly and by politicians' (P2). There is unanimity (P1-P6), however, that the 'rantings of the shock jocks and the media tabloids and all the rest of it' (P3) have produced a tense atmosphere. Contemporary public prosecutors can see themselves as misunderstood if not assailed from all sides. For them, the central challenge is perceived to be 'to protect the prosecution process from all external pressures, whether blatant or subtle, which can arise in a divided society' (Cowdery 2012: 18).

\section{Representing community}

In its assertions of independence, public prosecution commonly refers to founding statutes supported by judicial decision. ${ }^{22}$ These provide the constitutional footing to prosecutorial

\footnotetext{
${ }^{20}$ Professional and scholarly literature also discusses representations of prosecutors as zealots or moderates (Plater 2011: 2-3).

${ }^{21}$ For a summary of perspective see Sarat and Clarke 2008, p. 389.

${ }^{22}$ Deane $\mathrm{J}$ in $R v$. Whitehorn affirmed that 'prosecuting counsel in a criminal trial represents the State', (1983) 152 CLR 657; and see Plater (2011: 139).
} 
independence and their status as part of the apparatus of the state. ${ }^{23}$ Beyond constitutional legality, public prosecution claims normative roots in the privilege to 'represent community' (P2, P3, P4). That is, to prosecute 'on behalf of society' (Myjer, et al. 2009: 1) - 'the whole community' (P3). The normative and legal dissimilarity between the concepts and forms of Crown, state and community appear unacknowledged.

The term 'community' evokes a ductile, more exposed assortment of publics - 'those who can't protect themselves', 'the weak and vulnerable' (P2) who should be kept safe 'from aggression' (P4). At the same time, and linked with the curse of 'expectations', communities can become something wielded as a kind of threat (P1) but also in entreaty (P4). It is a source of those blatant and subtle external pressures. As a word community can obscure the fact that it 'is made up of many disparate groups and individuals with widely divergent views' (P5) and there is some cynicism in the perception that it can 'mean whatever a politician wants [it] to mean at a particular time' (P1).

Conceptualising the subjects of victim and accused as members of community are both abstracted and particularised for the former, and generally situated in rights discourse for the latter. The individual accused as rights bearing is uncontested - 'we do bend over backwards to be fair' (P6). Public prosecutors will easily turn to say 'we have to ensure that the accused is treated fairly' (P5, P6). ${ }^{24}$ There is equal readiness to reach for particular stories that act as exemplars for certain representations of victim. On the one hand, for example, there's the image that the victim is 'hysterical, out of control' (P1) and, on the other hand, those who 'have hope and optimism, are still kind and concerned' (P2). As rights-bearing individuals in the community, victims 'don't have any rights. No, certainly not' (P6). ${ }^{25}$ Being 'the state' requires

\footnotetext{
${ }^{23}$ The term constitutional is used here 'with reference to the legally established aims and powers of the public prosecutor, not to the constitution of any state'. Committee of Ministers (2000) The Role of Public Prosecution in the Criminal Justice System, Council of Europe, p.5.

${ }^{24}$ Fairness to the accused is prominent in the prosecution policy of all Australian Directors of Public Prosecution, and is protected in the United Nations Declaration of Human Rights and in the International Covenant on Civil and Political Rights. It is claimed that the protection of the accused person's right to a fair trial is a core if not the defining element to the prosecution's role as a Minister of Justice (Plater 2011: 31-32).

${ }^{25}$ Some argue that the idea of victims' rights should more properly 'be assessed on general principles' (Ashworth and Redmayne 2005: 49). The 1985 UN Declaration of Basic Principles of Justice for Victims of Crime and Abuse of Power is regarded in international law as 'soft' law.
} 
mindfulness of the imbalance in power and resources. This awareness is generally restricted to the accused rather than to other directly involved civilians (Dal Pont 2009).

It is declared that 'of course the victim is a member of the public'; but then '... one can't say I represent the public which means I represent the victim, therefore I am the victim's advocate ... to represent the community as a whole means that you take an objective approach' (P2). In the discourse, therefore, the idea of community is modelled as 'figments of fiction, of imagination' (P4). An answer to the question 'what's the cut of community' is that 'it's the greater community interest' for 'the greater good' (P2). It is a circular argument. Ultimately the prosecutor is left to 'take a holistic view of what's in the interests of the community' (P4).

As an alternative term, 'public' can allude to a more astringent entity. In this guise, the public guardian role depends on a distinct characterisation of a public in which criminal law and justice are required 'to guard against anarchy and vigilantism' (P2) and contain 'unrestrained passions, vengeance, criminal acts' (P5). Here the criminal law is simply 'to protect the society from the bad people' (P6). The prosecutor protects an excited public from itself (Hetherington 1989).

\section{Public interest}

Ideas of protecting of the community thread through prosecutors' projections of what is the 'public interest'. The term holds a central place in the ideology of public prosecution but, it is said, 'can't be found by way of mathematical or political calculation'. ${ }^{26}$ While being indeterminate and malleable it is also extraordinarily normatively resonant. It is claimed as 'the underlying philosophy' (P2) to prosecution guidelines. These then specify a long list of criteria that may be taken into account when deciding what is in the public interest - 'if you are looking for a peg to hang your coat on you might find one there' (P3). The policy frameworks conclude that, 'in many cases, of course, the interests of the public will only be served by the deterrent

\footnotetext{
${ }^{26}$ Gallop, G. (July 2010), 'The Curious Mix Known as the Public Interest', Sydney Morning Herald, viewed on 12 April 2013 at www.smh.com.au/opinion/politics/the-curious-mix-known-as-the-public-interest--20100712106cj.html.
} 
effect of an appropriate prosecution' ${ }^{27}$ In practice, however, thinking will turn to ask 'are there reasons as to why in the public interest nevertheless the case should not be prosecuted?' (P3, P6). In this ambivalent and media-saturated space it is suggested that the thing that Directors are most criticised for is not prosecuting' (P2). With the core two-part test through which the assessment is made, it will either be on the sufficiency of evidence or the public interest to which that criticism is directed.

When weighing up the public interest and linked to prosecutorial ethics it is said that a prosecutor should apply 'the highest standards to which the community would or should aspire if it were aware of all the facts and were equipped to make an objective and informed decision' (Crispin 1995: 181). At the same time this weighing up requires consciousness of 'several audiences' (P5) and different dimensions: it 'requires you to look back, to look out and to look forward'. Ultimately, 'acting in the public interest is taking that continuum, that historical continuum and balancing all the factors that are operating now in a way that will serve that continuum satisfactorily' (P3).

The public interest concept is fluid and contested in application: 'we have interests that countervail the public interest in all sorts of things' and there are 'no simple right answers' 'not always, not always' (P5). Figuring out the conceptual nuance and the delicacy to practice is largely confined to internal discussants - 'colleagues, their supervisors, with senior people' (P3). That is, 'informed by some shared understanding ... within the legal community' (P4). Engaging with the actual public on the nature and scope of their interests is largely formal - through speeches and presentations - and cautious (P2, P3, P4, P5, P6).

How public interest is more generally vernacularised in prosecution discourse does vary - in part because of the multiplicity of formal criteria - but there is a shared view of what it is not. That is, prosecution is a decision made free of any sectional or representational interests in the name of 'the public' (P1-6), never 'simply because it might get the media off my back' (P2),

\footnotetext{
${ }^{27}$ The criteria across Australian prosecuting authorities are mostly the same. The reference here is from the ACT Director of Public Prosecutions (1991), Prosecution Policy at 2.6, accessed on 11 April 2013 at www.dpp.act.gov.au/publications/prosecutions policy.
} 
or 'in some atavistic interest of somebody who is pressuring you into doing something' (P1). ${ }^{28}$ An individual, asking where they as a member of the public fit in the conception, might 'often think that the public interest is at one with theirs'. Consequently, prosecutors see little that is constructive arising from such 'inflammatory' discussion (P2). The preference is to conceive 'an independent statutory authority casting his or her mind over the entirety of the case' (P5) as properly arriving at a decision about the public interest in a particular circumstance that is 'buyable by the community' (P4).

What is also presumed buyable in the public interest is tolerance of 'an uneasy tension between prosecution and victim' (P4). Victim-oriented reforms are still regarded by some as a 'danger' and a 'throwback to medievalism' (P1). As a constituency, victims are contaminated with this danger. Prosecution authorities are 'frightened of being seen to be pandering to victims' (P4). Practically victims are 'expected to put up with whatever happened to them [in the witness box] and too bad' (P3). People who were 'caught up in the criminal justice system' (P3) are 'irrelevant' (P4). They can be conceived, on the one hand, as 'merely the vehicle by which the [community] norm has been broken' (P4) or simply as 'cannon fodder' (P6) for the machinery of criminal justice.

Ultimately it is prosecution prerogative to decide what is in the public interest at a crucial decision-making point within that machinery. 'Their decision has to be final ... I don't know of any other public official with quite the same role' (P4). As such, claiming a decision 'in the public interest' has a unique capacity to silence questioning. Elish Angiolini QC, SolicitorGeneral in Scotland, commented in 2005 that it can serve 'as a useful decoy to dazzle those who would otherwise probe decisions taken under that label' ${ }^{29}$

\footnotetext{
${ }^{28}$ In Australia as well as in England and Wales, the independence of the decision to prosecute from what is presumed to be the institutional interests of police is a matter of some debate (see Findlay et al. 2010: 160, and Ashworth and Redmayne 2005: 173).

${ }^{29}$ Angiolini, A. 'Public Prosecutor: Hero or villain,' Speech delivered at 'The Edinburgh Lectures,' 25 January 2005, cited in Plater (2011: 25).
} 


\section{Accountability}

With this degree of decision-making power, questions of accountability are grave. Ex-Directors acknowledge that 'the community generally has [no] high regard for the operational workings of our criminal justice system' (P5). But with this recognition public prosecutors walk a conceptual tightrope - they represent community as a greater, a holistic, an almost incandescent ideal; are responsive to community norms as they see it, and yet are extremely sensitive to contentions of accountability from community, or from sections of community. Responsiveness to changing community norms, for example in prosecuting offences such as domestic violence and child abuse as serious public concerns ${ }^{30}$ or indeed responsiveness to regional and local circumstances, ${ }^{31}$ is set in contrast to perceived obligations to resist a punitive public (P1, P3, P6) and to resist notions of direct answerability to the public or specific publics. Thus prosecution is conceived as distant as well as responsive.

Accountability is a layered notion. When viewed 'in a unitary mode that if you are accountable then you are beholden in some way or subservient or at the direction or at the behest of the person' then 'most prosecutors I suspect would, as soon as you talk about victims and accountability in the one phrase, run a mile' (P4). ${ }^{32}$ Consequently 'there [is] no mileage in explaining' prosecution decisions (P1). At another level, formal accountability as a state agency rests in 'superintendence' by the Attorney-General, annual reports, court rules and providing reasons for decision 'in certain circumstances' (P3). ${ }^{33} \mathrm{~A}$ mid-way between these points might accept that, where persons might be 'heavily invested in something, they are entitled to a proper explanation as best we can give them' (P2). Nonetheless, there is recognition that 'many prosecution decisions made by independent prosecutors are not reviewable by the Courts and it is important to maintain public confidence in the fairness, integrity and impartiality of

\footnotetext{
${ }^{30}$ Interviewees commented on the way their guidelines 'move' (P1) in relation to social mores. For further discussion on this point, see Hetherington (1989: 139) and more generally Young and Sanders (2004).

${ }^{31}$ Hetherington (1989: 79) and Council of Europe (2000: 4).

32 Barristers have a duty to the administration of justice and to their client (see Australian Bar Association, Barristers' Conduct Rules, November 2010, p.1). However, the barrister in a prosecution role has no client but has a duty to the court (p.16) (and at a Federal level in the USA, see Gershman 2005). The prosecutor owes no enforceable duty of care to either the victim or the accused (Plater: 2011: 27). Krone describes three internal ways in which the prosecutorial role is controlled: control of authority, control of role and policy control (Krone 2012).

${ }^{33}$ For a statement about these formal accountabilities see Bugg, D. (2007) and Hetherington (1987: 8-9).
} 
prosecutors' (Bugg 2007: 7). However, with the spectre of invested others directing prosecutorial decision-making there is little to no specificity to depictions of accountability in the everyday prosecutorial world. It is unbound 'by any enforceable standard' ${ }^{34}$

Further, and central to debate about accountability, is the separation of private and public interests (P2). Contemporary prosecutors strongly assert that the Crown is acting for the public, the people, the State' (P1). It is as if these are indivisible. The institutional depiction is that 'when you come to the court room there are only two parties, one is the community or the Crown (the prosecutor) and the other is the accused. There is no place at the bar table for the victim in our system' (P3). The rejection of the interests and involvement of particular publics in the form of the victim complainant on the grounds that these are private (and therefore not legitimate) is emphatic. It is an institution with 'a great deal of power' (P3).

\section{Concluding discussion}

The discourse of legal elites may be a 'fantasy', 'an imagination of an ideal social order' (Gordon 2012: 209). In the fog of law, much of it is 'unworkably vague' (Plater 2011: 166). Elites may also be credited with 'disproportionate influence' (Gordon 1984: 122) especially where the routine minutia of the mandarin is 'almost totally commonplace'. At the same time, public prosecution 'is legally approved but generally unchecked, [and] legally exceptional'. ${ }^{35}$ In liberal democracies, prosecutors enact 'the logic of sovereignty' through daily decisions to whom the law will or will not apply (Sarat and Clarke 2008: 387 and 411). Like sovereigns of old, prosecuting authorities assert 'monopolistic control' (Cardemas 1986: 361; Hay 1983). They are sovereign, state, public and community in one. Theirs is a 'presumption of legitimacy' (Chomsky 1969: 9). 'Trust me' (P6) says the prosecutorial mandarin.

\footnotetext{
${ }^{34}$ Then ACT DPP Richard Refshauge (2010: 1) referencing Ronald Dworkin's delineation between strong and weak discretion See Dworkin, R. (1977), Taking Rights Seriously, Harvard University Press, Cambridge. Sarat and Clarke discuss the case law on this point with regard to the US Supreme Court (2008: 394-404).

${ }^{35}$ Scope for review of prosecution decisions is extremely narrow (Plater 2012). In Australia, see Maxwell v R [1996] HCA 46; (1996) 184 CLR 501 (15 March 1996). In contra for the UK, see Spencer (2010, pp. 148-51). A decision to prosecute is reviewable by courts but the decision not to is 'largely immune from public or even judicial scrutiny and review' (Australian Law Reform Commission 1980: 61). Note also a new initiative of the UK CPS on victims' right of review located at www.cps.gov.uk/victims witnesses/victims right to review/index.html [retrieved 4 October 2016].
} 
As an ideology, the discourse codes discussed in this chapter are a kind of 'institutional fundamentalism' (Sen 2009: 83) that emphasise order, objectivity and subordination to prosecution decisions. These are the voices of 'benevolently competent authority' (Duff 2001: 8) where exclusivity is sustained by an 'official-centric' jurisprudence (Marcus and Waye 2004: 114) and resonant historic references. However an ideology 'does not passively exist as a form of dominance. It has continually to be renewed, recreated, defended, and modified' (Williams 1997: Preface xx). The affirmation and reaffirmation of prosecutors' custodianship of core concepts maintains discourse fluidity that is sufficiently robust to respond to political challenges to institutional independence, ${ }^{36}$ as well as malleable enough for interacting with different public groups on decision-making.

The skill of the modern bureaucratic state is to portray moderation - to look competent, appear benign and to nestle in neutral phraseology that 'is capable of compelling universal acceptance' (Bourdieu 1987: 818). Mandarin pronouncements on the body of ideas, beliefs and claims that comprise liberal legal ideology consecrate particular norms and practices.

Hegemony is the capacity to fashion a field according to this world view as well as capacity to require it. ${ }^{37}$ Prosecution mandarins not only define what is within the purview of the law, but can compel conformity with that vision. It is through the claim to be the entity representing public and the mandate to determine who and what among the publics are legitimated, and combined with definitional authority on the interests of that public that the ideological power of prosecution achieves pre-eminence. Their capacity and authority to act unbound is revealing of where power resides in criminal justice.

\footnotetext{
${ }^{36}$ I thank Professor Pierre de Vos for this point. His comment was reflecting on the challenges facing South Africa's National Prosecuting Authority. The comment put me in mind of Robert Gordon's explanation that critical legal historians aim to 'lift the veil of power and need to expose the legal elements of their composition' (1984: 109); but this is another paper! Comments made at the Prosecution Workshop, International Institute for the Sociology of Law, Onati, Spain 29 July 2016.

37 Here I rely on Raymond Williams' exposition of 'hegemony' as a dynamic process as much as it is a system of dominance. Hegemony is adaptive and not necessarily total (Williams 1977, chapter 6).
} 


\section{References}

Ashworth, A and Redmayne, M (2010) The Criminal Process $4^{\text {th }}$ edn (Oxford, Oxford University Press).

Bandyopadhyay, S and McCannon, B (2014) 'The Effect of the Election of Prosecutors on Criminal Trials' 161(1-2) Public Choice 141, 156.

Blumenthal, S (2012) 'Of Mandarins, Legal Consciousness and the Cultural Turn in American Legal History' 37(1) Law and Social Inquiry 167, 186.

Boylan, R (2005) 'What do Prosecutors Maximize? Evidence from the Careers of US Attorneys' 7(2) American Law and Economics Review 379, 402.

Bourdieu, P (1987) 'The Force of Law: Towards a Sociology of the Juridicial Field' 38 The Hastings Law Journal 814, 853.

Braithwaite, J (2001) 'Crime in a Convict Republic 64 The Modern Law Review 11, 50.

Brubacher, M (2004) 'Prosecutorial Discretion within the International Criminal Court' 2(1) Journal of International Criminal Justice 71, 95.

Bugg, D (2007) 'The independence of the prosecutor and the rule of law' Speech to the Conference, Rule of Law: challenges in a changing world, Brisbane. Available at http://www.cdpp.gov.au/Director/Speeches/20070831db.aspx

Cardenas, J (1986) 'The Crime Victim in the Prosecutorial Process' 9(2) Harvard Journal of Law and Public Policy 358, 398.

Chouliaraki, L and Fairclough, N (1999) Discourse in Late Modernity: Rethinking Critical Discourse Analysis (Edinburgh, Edinburgh University Press).

Chomsky, N (1969) American Power and the New Mandarins (New York, NY: Pantheon Books).

Conti, J and O'Neil, M (2007) 'Studying Power: Qualitative Methods and the Global Elite' 7(1) Qualitative Research 63, 82.

Corns, C (2000) ‘Police Summary Prosecutions in Australia and New Zealand: Some Comparisons' 19 University of Tasmania Law Review 280, 310. 
Cowdery, N (2012) 'Challenges to Prosecution Discretion' 39(1) Commonwealth Law Bulletin 17, 20.

Cowdery, N (2012) 'Reflections of a (re) tired DPP' 44(3) Australian Journal of Forensic Sciences 219, 226.

Crispin, K (1995) 'Prosecutorial Ethics' in S Parker and C Sampford (eds), Legal Ethics and Legal Practice: Contemporary Issues (Oxford, Clarendon Press).

Dal Pont, G (2009) Lawyers' Professional Responsibility in Australia and New Zealand 4th edn (Sydney, Lawbook Co).

Davis, A (2007) Arbitrary Justice: the Power of the American Prosecutor (New York, NY: Oxford University Press).

Davis, K (1975) Police discretion (West Publishing Company).

Del Ponte, C (2011) Madame Prosecutor: Confrontations with Humanity's Worst Criminals and the Culture of Impunity (New York, NY: Other Books).

Duff, RA (2001) Punishment, Communication, and Community (Oxford, Oxford University Press).

Elias, N (1939/2000) The Civilising Process (Oxford, Blackwell).

Emsley, C (2005) 'Filling in, adding up, moving on: Criminal Justice History in Contemporary Britain' Crime, History and Societies 9(1), 117-138.

Eisenstein, J (1978) Counsel for the United States: US Attorney in the Political and Legal Systems (Baltimore, MD: John Hopkins University Press).

Findlay, M, Odgers, S and Yeo, S (2010) Australian Criminal Justice $4^{\text {th }}$ edn (South Melbourne, Oxford University Press).

Garland, D (2001) The culture of control: crime and social order in contemporary society (Oxford, Oxford University Press).

Gershman, B (2005) 'Prosecutorial Ethics and Victims' Rights: The Prosecutor's Duty of Neutrality' 9 Lewis and Clarke Law Review 563, 564. 
Gilliéron, G (2014) Public Prosecutors in the United States and Europe: A Comparative Analysis with Special Focus on Switzerland, France and Germany (Springer International Publishing).

Godfrey, B and Dunstall, G (eds) (2005) Crime And Empire - 1840-1940: Criminal Justice in Local and Global Context (Devon, Willan).

Gordon, R (2012) ‘Critical Legal Histories Revisited: a Response' 37(1) Law and Social Inquiry 200, 215.

Gordon, R (1984) 'Critical Legal Histories' 36(57) Stanford Law Review 57, 125.

Harris, JW (1997) Legal Philosophies $2^{\text {nd }}$ edn (London, Butterworths).

Hay, D (1983) 'Controlling the English Prosecutor’ 21 Osgoode Hall Law Journal 165.

Hetherington, T (1989) Prosecution and the Public Interest (London, Pergamon Press).

Hetherington, T (1987) 'Prosecutor and the Public Interest' 19 The Bracton Law Journal 7, 11.

Holder, R (2013) Just Interests: victims, citizens and the potential for justice PhD Thesis

(Canberra, The Australian National University). Located at

http://hdl.handle.net/1885/11464

Hughes, R (2003) The Fatal Shore (London, Vintage).

Johnson, D (2002) The Japanese Way of Justice: Prosecuting Crime in Japan (Oxford, Oxford University Press).

Kearon, T and Godfrey, B (2007) 'Setting the Scene: a Question of History' in S Walklate (ed), Handbook of Victims and Victimology (Portland, OR: Willan Publishing).

Krone, T (2003) 'The Limits of Prosecution Authority' Regulatory Institutions Network (RegNet) Working Paper 18 (Canberra, The Australian National University).

Lacey, N (2001) 'In Search of the Responsible Subject: History, Philosophy and Social Sciences in Criminal Law Theory' 64 The Modern Law Review 350, 371.

Langbein, J (2003) The Origins of the Adversary Criminal Trial (Oxford, Oxford University Press). 
Lievore, D (2005) No Longer Silent: A Study of Women's Help-Seeking Decisions and Service Responses to Sexual Assault (Canberra, Australian Institute of Criminology).

Luna, E and Wade, M (eds) (2012) The Prosecutor in Transnational Perspective (Oxford, Oxford University Press).

McConville, M and Wilson, G (eds) (2002) The Handbook of the Criminal Justice Process (Oxford, Oxford University Press).

Marcus, P and Waye, V (2004) 'Australia and the United States: Two Common Criminal Justice Systems Uncommonly at Odds' 12(1) Tulane Journal of International \& Comparative Law $09,79$.

Mellon, L, Jacoby, J, and Brewer, M (1981) 'The Prosecutor Constrained by his Environment: A New Look at Discretionary Justice in the United States' 72(1) The Journal of Criminal Law and Criminology 52, 81.

Meuser, M and Nagel, U (2009) 'The Expert Interview and Changes in Knowledge Production' in A Bogner, B Littig and W Menz (eds), Interviewing Experts (London, Palgrave Macmillan).

Morris, Z (2009) 'The Truth about Interviewing Elites 29(3) Politics 209, 217.

Myjer, E, Hancock, B and Cowdery, N (eds) (2009), Human Rights Manual for Prosecutors (Nijmegen, The Netherlands: Wolf Legal Publishers).

Neal, D (1991) The Rule of Law in a Penal Colony: Law and Power in Early New South Wales (Cambridge, Cambridge University Press).

Pateman, C (1970) Participation and Democratic Theory (Cambridge, Cambridge University Press).

Pfadenhauer, M (2009) 'At Eye Level: the Expert Interview - a Talk between Expert and Quasiexpert' in Bogner et al (eds), Interviewing Experts (London, Palgrave Macmillan).

Plater, D (2011) The Changing Role of the Modern Prosecutor: has the notion of 'Minister of Justice' outlived its usefulness? PhD Thesis, University of Tasmania available at http://eprints.utas.edu.au/10743/2/David Plater whole.pdf 
Refshauge, R (2002) 'Prosecutorial Discretion in Australia' in G Moens and R Biffot (eds), The Convergence of Legal Systems in the 21st Century, An Australian Approach (Brisbane, The Australian Institute of Foreign and Comparative Law).

Reydams, L, Wouters, J and Ryngaert, C (eds) (2012) International Prosecutors (Oxford, Oxford University Press).

Rock, P (2004) 'Victims, Prosecutors and the State in Nineteenth Century England and Wales' 4(4) Criminal Justice 331, 354.

Rozenes, M (1996) 'Prosecutorial Discretion in Australia Today' speech to the Conference, Prosecuting Justice, Melbourne. Australian Institute of Criminology, viewed on 17 April 2013 at http://www.cdpp.gov.au/Director/Speeches/19960418mr.aspx

Sanders, A (ed) (1996) Prosecution in Common Law Jurisdictions (Aldershot, Dartmouth Publishing Company).

Sarat, A and Clarke, C (2008) 'Beyond Discretion: Prosecution and the Logic of Sovereignty, and the Limits of Law' 33(2) Law and Social Inquiry 387, 416.

Sen, A (2009) The Idea of Justice (Cambridge, MA: The Belknap Press of Harvard University Press).

Terdiman, R (1987) 'The Force of Law: Translator's Introduction' 38 Hastings Law Journal 805, 813.

Tonry, M (ed) (2012) Prosecutors and Politics: a Comparative Perspective (Chicago, IL: University of Chicago Press).

Wacks, R (2006) Philosophy of Law: a Very Short Introduction (Oxford, Oxford University Press).

Wade, M (2008) 'The Januses of Justice: How Prosecutors Define the Kind of Justice Done Across Europe' 16 European Journal of Crime, Criminal Law and Criminal Justice 433, 455.

Wade, M, De Cavarlay, B, and Zila, J (2008) 'Tinker, Tailor, Policy-maker: The Wider Context of Prosecution Service Work' 14(2-3) European Journal on Criminal Policy and Research 181, 190. 
Williams, R (1997) Marxism and Literature (Oxford, Oxford University Press).

Woods, G (2002) A History of Criminal Law in New South Wales: the Colonial Period 1788-1900 (Sydney, The Federation Press).

Wright, R and Levine, K (2014) 'The Cure for Young Prosecutors' Syndrome' 56(4) Arizona Law Review 1065, 1128).

Wright, R, Levine, K and Miller, M (2014) 'The Many Faces of Prosecution' 1(27) Stanford Journal of Criminal Law and Policy 27, 47.

Young, I (1987) 'Impartiality and the Civic Public' in S Benhabib \& D Cornell (eds), Feminism as Critique (Minneapolis, University of Minnesota Press).

Young, R and Sanders, A (2004) 'The Ethics of Prosecution Lawyers' 7(2) Legal Ethics 190, 209. 